\title{
Serial assessment of myocardial T2 in Duchenne muscular dystrophy
}

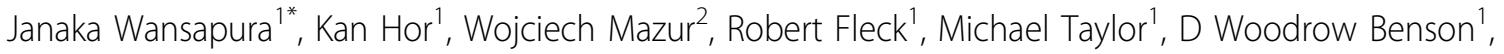 \\ William Gottliebson ${ }^{1}$
}

From 2011 SCMR/Euro CMR Joint Scientific Sessions

Nice, France. 3-6 February 2011

\section{Background}

Duchenne Muscular Dystrophy (DMD), a lethal $\mathrm{X}$-linked skeletal and cardiac myopathy, affects $1 / 3500$ males[1-2]. MRI studies have shown occult ventricular dysfunction and myocardial fibrosis in DMD patients. Previously we used the Full Width of Half Maximum ( $F W H M$ ) of T2 distribution in LV to quantify the myocardial structural heterogeneity in DMD patients. In DMD subject groups, we showed that FWHM of the T2 histogram rose progressively with age and decreasing $\mathrm{EF}$ indicating that functional impairments could be associated with pre-existing abnormalities in tissue structure in young DMD patients. In this study we assessed the $\mathrm{T} 2$ distribution in DMD patients at two time points. We hypothesized that serial FWHM changes can be detected in individual DMD patients during a time when left ventricular ejection fraction (EF) changes are insignificant.

\section{Methods}

MRI Data of eighteen DMD patients obtained at two time points were analyzed (mean $=12$ years, range $=8-18$ years) with a mean time of 2.3 years between the studies. Spin echo images of the left ventricle in the short axis plane were acquired using a black blood dual spin echo method. Imaging parameters were: Slice thickness $=5 \mathrm{~mm}$, in plane resolution $=1.4 \mathrm{~mm} \times 1.4 \mathrm{~mm}$, echo train length $=5$, Echo times: $\mathrm{TE}_{1}=6 \mathrm{~ms}, \mathrm{TE}_{2}=34 \mathrm{~ms}$. A histogram of LV T2 distribution with bin size equal to $1 \mathrm{~ms}$ was constructed for each subject. The Full Width at Half Maximum ( $F W H M)$ was calculated after applying box car averaging. The $F W H M$ was defined as the width of the histogram at half the maximum height.

${ }^{1}$ Cincinnati Children's Hospital, Cincinnati, OH, USA

Full list of author information is available at the end of the article

\section{Results and conclusions}

In the interval between studies the $F H W M$ increased in all but two patients (89\%). The average increase in FWHM was $6.8 \pm 3.9$ ms. The mean T2 increased in 5 patients while it declined in 13 patients. In a previous study we showed that FWHM did not change with age in normal subjects. Thus increase in T2 heterogeneity quantified by $F W H M$ indicates progression of disease over a relatively short period.

\section{Author details}

'Cincinnati Children's Hospital, Cincinnati, OH, USA. ${ }^{2}$ Christ Hospital,

Cincinnati, OH, USA.

Published: 2 February 2011

doi:10.1186/1532-429X-13-S1-P282

Cite this article as: Wansapura et al: Serial assessment of myocardial T2

in Duchenne muscular dystrophy. Journal of Cardiovascular Magnetic

Resonance 2011 13(Suppl 1):P282.

Submit your next manuscript to BioMed Central and take full advantage of:

- Convenient online submission

- Thorough peer review

- No space constraints or color figure charges

- Immediate publication on acceptance

- Inclusion in PubMed, CAS, Scopus and Google Scholar

- Research which is freely available for redistribution

\section{Biomed Central}

(c) 2011 Wansapura et al; licensee BioMed Central Ltd. This is an open access article distributed under the terms of the Creative Commons Attribution License (http://creativecommons.org/licenses/by/2.0), which permits unrestricted use, distribution, and reproduction in any medium, provided the original work is properly cited. 